\title{
Influence of Sedimentary Fe and Mn on the Oxygenation of Overlying Waters in Dam Reservoirs
}

\author{
Piotr Koszelnik ${ }^{1 *}$, Lilianna Bartoszek ${ }^{1}$ \\ 1 Department of Environmental Engineering and Chemistry Rzeszów University of Technology, al. Powstańców \\ Warszawy 6, 35-959 Rzeszów, Poland \\ * Corresponding author's e-mail: pkoszel@prz.edu.pl
}

\begin{abstract}
This paper reports the work to determine the impact that concentrations of manganese (Mn) and iron ( $\mathrm{Fe})$ in the bottom sediments of shallow dam reservoirs exert upon the dissolved oxygen concentrations of overlying waters. Specifically, the work was conducted in the period of 2013-2014 in six shallow artificial reservoirs located in SE Poland. The waters of all the reservoirs studied are relatively well oxygenated, though both supersaturation and anoxic conditions are observed seasonally across the $50-150 \%$ range. The reported reactions of bottom sediments were between $\mathrm{pH} 7.7$ and 8.2, while the mean concentrations of $\mathrm{Mn}$ and Fe were found to vary widely from site to site (Mn from 0.068 to $1.48 \mathrm{~g} / \mathrm{kg}$ d.w. and Fe from 2.48 to $24.0 \mathrm{~g} / \mathrm{kg} \mathrm{d}$.w.). It was not possible to demonstrate any direct relationship between sediment $\mathrm{Fe}$ and $\mathrm{Mn}$ concentrations, the $\mathrm{Mn} / \mathrm{Fe}$ ratio or $\mathrm{pH}$ on the one hand and the oxygenation of reservoir waters on the other. However, multiple regression analysis did allow for the identification of a significant influence of both $\mathrm{Mn}$ content and sediment $\mathrm{pH}$ on the oxygen concentration in reservoir waters. In simple terms, both an increase in $\mathrm{Mn}$ and a decrease in $\mathrm{pH}$ can be said to result in more fully aerobic conditions in waters.
\end{abstract}

Keywords: manganese, iron, dissolved oxygen, dam reservoir

\section{INTRODUCTION}

Iron (Fe) and manganese (Mn) are elements commonly present in the aquatic environment [Kaleta et al. 2007, Czaplicka et al. 2017]. While mainly natural in origin, they can also derive from anthropogenic sources, especially in surface waters [Grochowska and Tandyrak 2009, Molenda 2013]. Equally, the concentrations in bottom sediments are typically many times higher than those in waters as such, given occurrence of these elements in the form of salts that are only sparingly soluble. Both elements act to render phosphate inactive, in this way limiting processes of eutrophication [Bartoszek and Tomaszek 2011]. The effect is highly dependent on the oxidation and reduction of the coupled pairs $\mathrm{Fe}(\mathrm{II}) / \mathrm{Fe}$ (III) and $\mathrm{Mn}(\mathrm{II}) / \mathrm{Mn}(\mathrm{IV})$, which result either in precipitation or dissolution - commonly with phosphate [Gantzer et al. 2009, Naeher et al. 2013, Dunalska et al. 2015]. A further connected result may be intensification of the processes by which autochthonous organic matter is first produced and then decomposes, and the latter process may in turn give rise to oxygen deficits in the near-bottom zone.

Equally, as internal loading with phosphates is the cause of progressive degradation in many ecosystems of both natural and artificial bodies of water [Kowalczewska-Madura et al. 2010, Zeleňáková et al. 2013], the dynamics to the oxidation and reduction of Fe and $\mathrm{Mn}$ can be assumed to exert an indirect influence on the process, presumably in line with the concentrations of the latter that are actually present in bottom sediments [Bartoszek and Tomaszek 2008]. In fact, the process may have yet-further consequences, not least impairment of the quality of water for use and/or the emission of greenhouse gases and odours to the atmosphere [Grabas et al. 2011, Gruca-Rokosz et al. 2011, Gruca-Rokosz and Tomaszek 2015]. 
The work described in this paper has concerned the impact the $\mathrm{Mn}$ and $\mathrm{Fe}$ concentrations in the bottom sediments of shallow dam reservoirs are able to exert on the dissolved oxygen concentrations in overlying waters. Given that the elements under study increase the retention potential of bottom sediments against phosphates, they may serve as an intermediate indicator of ecosystem resistance. The knowledge on this will therefore prove useful, given the interest in trying to safeguard such aquatic ecosystems against eutrophication.

\section{STUDIED SITES AND METHODS USED}

The samples of bottom sediment were taken at 15 sampling sites in 6 artificial reservoirs located in SE Poland. The characteristics of the reservoirs and sites studied are as shown in Table 1. The sediment was collected nine times through the 2013-2014 period, using a gravity sediment corer (KC Kajak of Denmark). The top $(0-5 \mathrm{~cm})$ layer was used in chemical analysis following drying. Microwave mineralization $\left(\mathrm{HNO}_{3}, 2-4.5 \mathrm{MPa}\right)$ was applied to allow for $\mathrm{Mn}$ and $\mathrm{Fe}$ determinations using an ICP spectrometer (Integra, GBC). The results were calculated as $\mathrm{g}$ of element vs. $\mathrm{kg}$ dry weight of sediment. The $\mathrm{pH}$ of deionized water extracts was also measured in the laboratory, while dissolved oxygen $\left(\mathrm{O}_{2}\right)$ and temperature were recorded in situ using a portable multimeter (MultiLine WTW). All statistical analysis was performed in Statistica software package.

\section{RESULTS}

The waters under study were found to be relatively well-oxygenated, with the average $\mathrm{O}_{2}$ concentration in the range $7.38 \mathrm{mg} / \mathrm{L}$ (BL12) to 10.20 $\mathrm{mg} / \mathrm{L}$ (OZ6). The analysis of seasonal variation in water saturation with oxygen $\left(\mathrm{XO}_{2}\right)$ indicates that for most of the sites tested, values were in the $75-100 \%$ range (Fig. 1). Equally, some of the sites at Brzóza Królewska, Ożanna and Rzeszów reservoirs were characterized by supersaturation, mainly during summer periods. In turn, Cierpisz and Blizne reservoirs reported a high degree of hypoxia, given the figures for saturation below $60 \%$ (Fig. 1). The supersaturation of water with oxygen can be observed in eutrophic, shallow ecosystems, in the summer, when the processes of photosynthesis can outpace the oxygen consumption. The deficiencies may in turn indicate high oxygen consumption within bottom sediments, in the absence of any possibility for these shortages to be made good from sources other than the atmosphere [Stańczykowska-Piotrowska 1990, Wójcik 2016].

Table 2 compiles statistics that present the results obtained. The Fe content was found to vary across a wide range. In Rzeszów and Blizne reservoirs, as well as some sites in Kamionka reservoir, the values were in the range of 13.38-24.00 $\mathrm{g} / \mathrm{kg}$. The other reservoirs were in turn characterized by the values in the $2.48-7.35 \mathrm{~g} / \mathrm{kg}$ range. In Blizne reservoir, a Mn concentration over $1.2 \mathrm{~g} / \mathrm{kg}$ was measured, while the corresponding figure for Rzeszów reservoir was of about $0.5 \mathrm{~g} / \mathrm{kg}$ d.m. Elsewhere, the values were below $0.2 \mathrm{~g} / \mathrm{kg}$. The concentrations of the two elements studied were correlated $\left(r^{2}=0.5517, p=0.0015\right)$. The sediments were of alkaline reaction, with me-

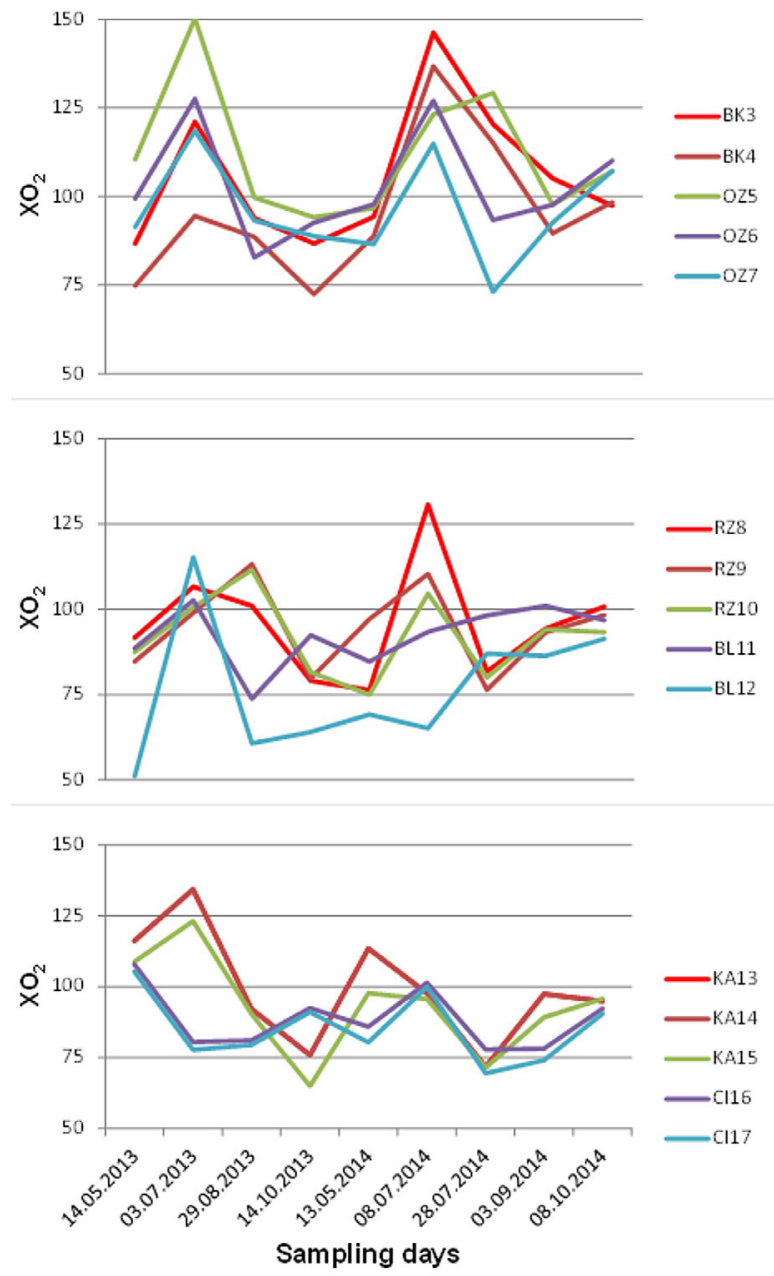

Fig. 1. Seasonal variability of percent oxygen saturation 
Table 1. Characteristics of studied reservoirs (own data)

\begin{tabular}{|c|c|c|c|c|c|c|c|c|c|c|c|c|c|}
\hline \multirow[t]{2}{*}{ Reservoir } & \multirow[t]{2}{*}{$\begin{array}{l}\text { Coor- } \\
\text { dinate }\end{array}$} & \multirow[t]{2}{*}{$\begin{array}{c}\text { River } \\
\text { (Stream) }\end{array}$} & \multirow{2}{*}{$\begin{array}{c}\text { Volume } \\
10^{3} \mathrm{~m}^{3}\end{array}$} & \multirow{2}{*}{$\begin{array}{c}\begin{array}{c}\text { Depth } \\
\text { mean } \\
\text { (max.) }\end{array} \\
\mathrm{m}\end{array}$} & \multirow{2}{*}{ 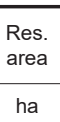 } & \multirow{2}{*}{$\begin{array}{c}\begin{array}{c}\text { Hydraulic } \\
\text { retention } \\
\text { time }\end{array} \\
\text { day }\end{array}$} & \multirow{2}{*}{$\begin{array}{c}\begin{array}{c}\text { Catchment } \\
\text { area }\end{array} \\
\text { km2 }\end{array}$} & \multirow{2}{*}{$\begin{array}{c}\text { Urban } \\
\%\end{array}$} & \multirow{2}{*}{$\begin{array}{c}\text { Forestry } \\
\%\end{array}$} & \multirow{2}{*}{$\begin{array}{c}\begin{array}{c}\text { Agricul- } \\
\text { ture }\end{array} \\
\%\end{array}$} & \multirow{2}{*}{$\begin{array}{c}\text { Pasture, } \\
\text { meadows }\end{array}$} & \multirow{2}{*}{$\begin{array}{l}\text { Studied } \\
\text { site }\end{array}$} & \multirow{2}{*}{$\begin{array}{r}\begin{array}{r}\text { Site } \\
\text { depth }\end{array} \\
m\end{array}$} \\
\hline & & & & & & & & & & & & & \\
\hline \multirow{2}{*}{$\begin{array}{c}\text { Brzóza } \\
\text { Królewska }\end{array}$} & \multirow{2}{*}{$\begin{array}{l}50^{\circ} 14^{\prime} \mathrm{N} \\
22^{\circ} 19^{\prime} \mathrm{E}\end{array}$} & \multirow{2}{*}{ Tarlaka } & \multirow{2}{*}{50} & \multirow{2}{*}{$0.7(1.5)$} & \multirow{2}{*}{7.05} & \multirow{2}{*}{2.5} & \multirow{2}{*}{30.4} & \multirow{2}{*}{10} & \multirow{2}{*}{30} & \multirow{2}{*}{40} & \multirow{2}{*}{20} & BK3 & 1.2 \\
\hline & & & & & & & & & & & & BK4 & 1.2 \\
\hline \multirow{3}{*}{ Ożanna } & \multirow{3}{*}{$\begin{array}{l}50^{\circ} 17^{\prime} \mathrm{N} \\
22^{\circ} 31^{\prime} \mathrm{E}\end{array}$} & \multirow{3}{*}{ Złota Rzeka } & \multirow{3}{*}{275} & \multirow{3}{*}{$1.4(3.7)$} & \multirow{3}{*}{20} & \multirow{3}{*}{3.5} & \multirow{3}{*}{136.3} & & & & & OZ5 & 1.2 \\
\hline & & & & & & & & 8 & 36 & 28 & 28 & OZ6 & 1.3 \\
\hline & & & & & & & & & & & & $\mathrm{OZ7}$ & 1.5 \\
\hline & & & & & & & & & & & & RZ8 & 1.0 \\
\hline Rzeszów & $\begin{array}{l}50^{\circ} 00^{\prime} \mathrm{N} \\
21^{\circ} 59^{\prime} \mathrm{F}\end{array}$ & Wisłok & 1800 & $0.6(4.9)$ & 68.2 & 0.8 & 2025 & 10 & 20 & 55 & 15 & RZ9 & 1.0 \\
\hline & & & & & & & & & & & & RZ10 & 1.0 \\
\hline 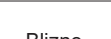 & $49^{\circ} 44^{\prime} \mathrm{N}$ & f & 127 & 1000 & OGe & 100 & 120 & 0 & 27 & 52 & 10 & BL11 & 1.2 \\
\hline Blizne & $22^{\circ} 00^{\prime} \mathrm{E}$ & Łądzıerz & 131 & $1.6(3.9)$ & 8.66 & 18.0 & 12.0 & 2 & 27 & 53 & 18 & BL12 & 1.3 \\
\hline & & & & & & & & & & & & KA13 & 1.3 \\
\hline Kamionka & $\begin{array}{l}50^{\circ} 08^{\prime} \mathrm{N} \\
21^{\circ} 40^{\prime} \mathrm{E}\end{array}$ & $\begin{array}{l}\text { Tuszymka } \\
\text { Duża }\end{array}$ & 105 & $1.5(3)$ & 7 & 4.8 & 84.8 & 12 & 35 & 30 & 23 & KA14 & 1.6 \\
\hline & & & & & & & & & & & & KA15 & 1.7 \\
\hline Ciprnicz & $50^{\circ} 09^{\prime} \mathrm{N}$ & Tuszymka & 20 & $0915)$ & 23 & 12 & 545 & 8 & 3 & 35 & 14 & Cl16 & 1.2 \\
\hline Cherpisz & $21^{\circ} 43^{\prime} \mathrm{E}$ & Duża & 22 & $.9(1.0)$ & 2.0 & 1.2 & 54.0 & 0 & 40 & 30 & 14 & Cl17 & 1.2 \\
\hline
\end{tabular}

Table 2. Variability of studied bottom sediment parameters

\begin{tabular}{|c|c|c|c|c|c|c|c|c|c|c|c|c|c|c|c|c|c|c|c|c|}
\hline Site & & $\mathrm{Fe}$ & $\mathrm{Mn}$ & $\mathrm{pH}$ & $\mathrm{O}_{2}$ & $\begin{array}{c}100 \cdot \\
\mathrm{Mn} / \mathrm{Fe}\end{array}$ & Site & & $\mathrm{Fe}$ & $\mathrm{Mn}$ & $\mathrm{pH}$ & $\mathrm{O}_{2}$ & $\begin{array}{c}100 \cdot \\
\mathrm{Mn} / \mathrm{Fe}\end{array}$ & Site & & $\mathrm{Fe}$ & $\mathrm{Mn}$ & $\mathrm{pH}$ & $\mathrm{O}_{2}$ & $\begin{array}{c}100 \\
\mathrm{Mn} / \mathrm{Fe}\end{array}$ \\
\hline \multirow{4}{*}{ BK3 } & Mean & 2.48 & 0.09 & 8.38 & 9.83 & 3.63 & \multirow{4}{*}{ RZ8 } & Mean & 21.0 & 0.541 & 8.37 & 9.02 & 2.58 & \multirow{4}{*}{ KA13 } & Mean & 13.38 & 0.18 & 8.00 & 9.40 & 1.35 \\
\hline & Min. & 1.73 & 0.05 & 7.79 & 8.83 & 2.89 & & Min. & 18.0 & 0.436 & 8.08 & 7.17 & 2.42 & & Min. & 3.47 & 0.05 & 7.54 & 7.15 & 1.44 \\
\hline & Max. & 4.78 & 0.14 & 8.97 & 10.91 & 2.93 & & Max. & 23.8 & 0.665 & 8.89 & 10.8 & 2.79 & & Max. & 27.36 & 0.46 & 8.38 & 10.67 & 1.68 \\
\hline & SD & 0.90 & 0.02 & 0.4 & 0.7 & 2.22 & & SD & 1.8 & 0.08 & 0.2 & 1.2 & 4.44 & & SD & 7.5 & 0.1 & 0.2 & 1.3 & 1.33 \\
\hline \multirow{4}{*}{ BK4 } & Mean & 7.44 & 0.26 & 8.21 & 8.92 & 3.49 & \multirow{4}{*}{ RZ9 } & Mean & 24.0 & 0.652 & 8.52 & 8.95 & 2.72 & \multirow{4}{*}{ KA14 } & Mean & 4.24 & 0.068 & 8.01 & 9.27 & 1.60 \\
\hline & Min. & 3.05 & 0.08 & 7.47 & 7.94 & 2.62 & & Min. & 19.1 & 0.487 & 8.31 & 6.93 & 2.55 & & Min. & 2.36 & 0.036 & 7.20 & 6.05 & 1.53 \\
\hline & Max. & 15.22 & 0.48 & 8.75 & 10.77 & 3.15 & & Max. & 27.0 & 0.851 & 8.96 & 10.58 & 3.15 & & Max. & 9.53 & 0.155 & 8.56 & 11.53 & 1.63 \\
\hline & SD & 4.14 & 0.15 & 0.4 & 0.8 & 3.62 & & SD & 2.5 & 0.13 & 0.2 & 1.1 & 5.20 & & SD & 2.3 & 0.04 & 0.5 & 1.7 & 1.74 \\
\hline \multirow{4}{*}{ OZ5 } & Mean & 3.16 & 0.092 & 8.62 & 10.2 & 2.91 & \multirow{4}{*}{ RZ10 } & Mean & 22.2 & 0.598 & 8.55 & 8.71 & 2.69 & \multirow{4}{*}{ KA15 } & Mean & 6.74 & 0.117 & 7.93 & 8.67 & 1.74 \\
\hline & Min. & 1.31 & 0.034 & 8.01 & 9.2 & 2.60 & & Min. & 19.1 & 0.466 & 8.27 & 7.33 & 2.44 & & Min. & 1.72 & 0.035 & 7.48 & 5.96 & 2.03 \\
\hline & Max. & 8.04 & 0.283 & 9.18 & 12.0 & 3.52 & & Max. & 29.6 & 0.697 & 9.00 & 10.49 & 2.35 & & Max. & 14.19 & 0.246 & 8.53 & 10.14 & 1.73 \\
\hline & SD & 2.0 & 0.08 & 0.4 & 1.0 & 4.00 & & SD & 3.2 & 0.07 & 0.3 & 1.0 & 2.19 & & SD & 4.0 & 0.08 & 0.3 & 1.5 & 2.00 \\
\hline \multirow{4}{*}{ OZ6 } & Mean & 7.21 & 0.146 & 8.55 & 9.52 & 2.02 & \multirow{4}{*}{ BL11 } & Mean & 19.86 & 1.24 & 8.43 & 8.90 & 6.24 & \multirow{4}{*}{ Cl16 } & Mean & 2.49 & 0.071 & 7.77 & 8.31 & 2.85 \\
\hline & Min. & 2.74 & 0.080 & 7.75 & 7.59 & 2.92 & & Min. & 16.77 & 0.47 & 8.11 & 7.40 & 2.80 & & Min. & 1.41 & 0.035 & 6.98 & 6.31 & 2.48 \\
\hline & Max. & 12.54 & 0.263 & 9.53 & 11.95 & 2.10 & & Max. & 23.02 & 3.41 & 8.55 & 10.09 & 14.81 & & Max. & 4.22 & 0.130 & 8.22 & 9.81 & 3.08 \\
\hline & SD & 3.8 & 0.07 & 0.6 & 1.3 & 1.84 & & SD & 2.21 & 0.96 & 0.1 & 0.9 & 43.44 & & SD & 0.9 & 0.03 & 0.4 & 1.3 & 3.33 \\
\hline \multirow{4}{*}{ OZ7 } & Mean & 7.35 & 0.153 & 8.40 & 9.00 & 2.08 & \multirow{4}{*}{ BL12 } & Mean & 17.50 & 1.48 & 8.33 & 7.38 & 8.46 & \multirow{4}{*}{ Cl17 } & Mean & 3.12 & 0.080 & 7.91 & 8.05 & 2.56 \\
\hline & Min. & 1.25 & 0.066 & 7.50 & 5.97 & 5.28 & & Min. & 13.46 & 1.02 & 7.98 & 4.78 & 7.58 & & Min. & 2.42 & 0.043 & 7.38 & 5.76 & 1.78 \\
\hline & Max. & 14.66 & 0.382 & 9.40 & 11.73 & 2.61 & & Max. & 19.61 & 2.45 & 8.83 & 10.14 & 12.49 & & Max. & 4.09 & 0.122 & 8.53 & 9.70 & 2.98 \\
\hline & SD & 4.8 & 0.10 & 0.5 & 1.5 & 2.08 & & $\mathrm{SD}$ & 1.79 & 0.48 & 0.3 & 1.8 & 26.82 & & $\mathrm{SD}$ & 0.7 & 0.03 & 0.3 & 1.4 & 4.29 \\
\hline
\end{tabular}

dian $\mathrm{pH}$ values in the 7.77-8.62 range. The calculated values for the $100 \cdot \mathrm{Mn} / \mathrm{Fe}$ ratio varied from 1.35-1 (KA13) to 8.46-1 (BL12) and depended slightly on the Mn concentration in sediments $\left(r^{2}=0.3296, p=0.0252\right)$. However, no dependence on Fe was observed.

The analysis of the influence of the independent variables ( $\mathrm{Fe}, \mathrm{Mn}, \mathrm{pH}$ and $\mathrm{Mn} / \mathrm{Fe}$ ) on the dependent variable $\left(\mathrm{O}_{2}\right)$ is reported in Table 3. In practice, no significant relationships were found that would describe an impact of analyzed parameters describing bottom sediment on the dissolved oxygen concentrations in the waters studied.
Equally, the analysis of the influence of variables on the value of $\mathrm{O}_{2}$ using multiple regression found that the value of the required independent variable in relation to the remaining dependent variables was best described by the function:

$$
\mathrm{O}_{2}=-4.7427+1.1880 \mathrm{Mn}-1.7099 \mathrm{pH}
$$

The summary of the regression in relation to $\mathrm{O}_{2}$ (Table 4) shows how the above-mentioned model can account for $65 \%$ of the variability noted for the dependent variable. Incorporation of additional dependent variables does not improve the parameters of the model significantly, and, as 
Table 3. Influence of bottom sediment parameters on water oxygen content expressed as Pearson coefficient (R)

\begin{tabular}{|c|c|c|c|c|}
\hline Parameters & $\mathrm{Fe}$ & $\mathrm{Mn}$ & $\mathrm{pH}$ & $\mathrm{Fe} / \mathrm{Mn}$ \\
\hline $\mathrm{O}_{2}$ & 0.36586 & 0.31225 & -0.49837 & 0.294298 \\
\hline
\end{tabular}

Table 4. Summary of the multiple regression analysis

\begin{tabular}{|l|c|}
\hline \multicolumn{1}{|c|}{ Statistics } & Value \\
\hline$R$ of multiple correlation & 0.8093 \\
\hline$R^{2}$ of multiple correlation & 0.6549 \\
\hline Corrected $R^{2}$ & 0.5608 \\
\hline$F(3.11)$ & 6.9588 \\
\hline$P$ & 0.0068 \\
\hline Error of the estimation & 0.4618 \\
\hline
\end{tabular}

is clear from the above, the changes in the $\mathrm{pH}$ of reservoir bottom sediments have the greatest influence on the values recorded for $\mathrm{O}_{2}$.

The validity of the model was further demonstrated by analyzing the correlations between the sampled values for $\mathrm{O}_{2}$ and theoretical values (deriving from Eq. 1) (Fig. 2) Further confirmation is offered by the distribution of residuals close to the normal distribution (Fig. 3).

\section{DISCUSSION}

The observed concentrations of $\mathrm{Fe}$ and $\mathrm{Mn}$ in the bottom sediments of the reservoirs studied were lower than those obtained for other ecosystems in southern Poland. Czaplicka et al. [2017] reported the $\mathrm{Fe}$ concentrations in Czorsztyn, Dobczyce, Goczałkowice and Rybnik reservoirs of approx. $30 \mathrm{~g} / \mathrm{kg}$, with $\mathrm{Mn}$ in the $1.33-3.27 \mathrm{~g} / \mathrm{kg}$ range. The differences may result from the nature

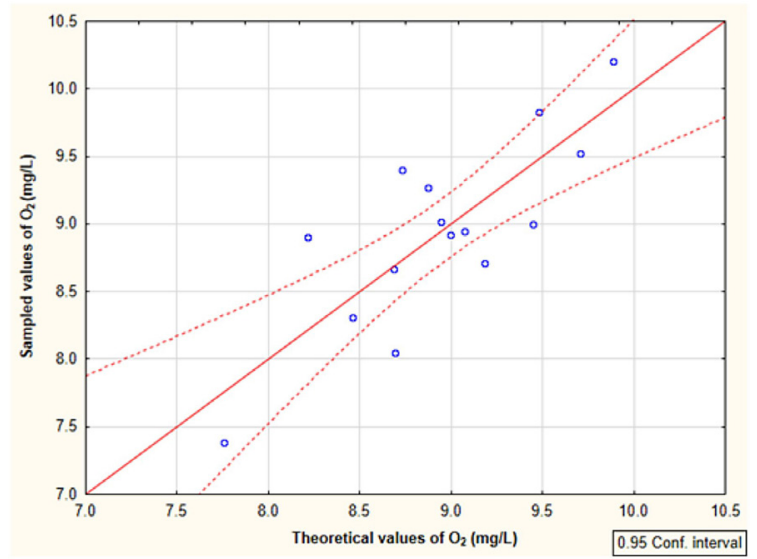

Fig. 2. Correlation between sampled values for $\mathrm{O}_{2}$ and theoretical values deriving from Eq. 1 and management of the catchment areas examined, e.g. reflecting slope or various potential origins of the elements [Karwacka et al. 2015].

The mobility of Mn reflects the occurrence in various forms under different redox conditions. Where anoxia is present, releases of $\mathrm{Mn}$ and $\mathrm{Fe}$ from the sediment into overlying water are observed, and this should theoretically dampen any growing deficiency of oxygen in overlying waters [Hou et al. 2013]. Given the lack of any significant relationship between the $100 \cdot \mathrm{Mn} / \mathrm{Fe}$ ratio and oxygen deficits arising in waters, there may be confirmation of the idea that both are released into the water column with similar efficiency. Nevertheless, the oxidation of $\mathrm{Fe}(\mathrm{II})$ is known to proceed more rapidly than that of $\mathrm{Mn}$ (II) [Naeher et al. 2013], while the involvement of numerous interdependent transformation processes leads to a complex pattern describing the presence of the redox-sensitive trace metals.

However, the Fe present in waters is not necessarily there on account of redox-related remobilization, as it can also be a tracer for terrigenous sources [Neaher 2012]. In light of this, the observed lack of a correlation with oxygen content in waters that was found to characterize the concentration of $\mathrm{Fe}$ in the sediment (and indirectly the release of that element from sediment) may indicate the diverse ways in which this element is transformed. In turn, the contribution of $\mathrm{Mn}$ to the multiple correlation model may confirm the

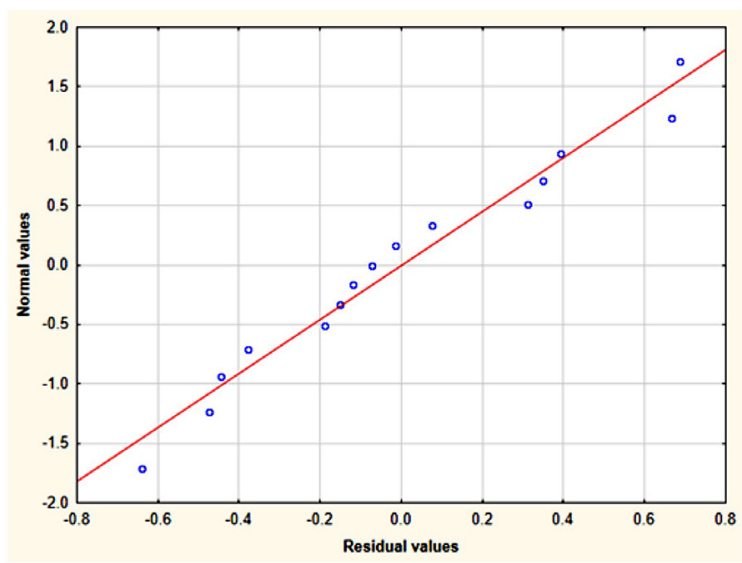

Fig. 3. Multiple regression results: the distribution of residuals close to the normal distribution 
predominance of Mn release into overlying water in association with phosphates, with the result of the presence of the latter being decreased oxygen content [Bryant et al. 2011]. Furthermore, while this impact is significant statistically (Table 4), it is less so in quantitative terms. From the model (Eq. 1), it appears that an increase in the concentration of $\mathrm{Mn}$ in sediments by $1.18 \mathrm{~g} / \mathrm{kg} \mathrm{d.m}$. (or in fact a reduced release of such a charge), enriches water by $1 \mathrm{mg} / \mathrm{L}$ of oxygen. However, the Mn concentrations in sediments are only about one-tenth as high, so an analogous proportion of the influence of the independent variable on the dependent should be assumed.

In addition, the model (Eq. 1) implies that a lowering of the $\mathrm{pH}$ value of the sediment by 1.70 units again enriches water in oxygen, by $1 \mathrm{mg} / \mathrm{L}$, with the proportions similar to those above again being maintained. Nevertheless, an inverse proportional effect of $\mathrm{pH}$ on the oxygen content in the supernatant is in fact reported widely [Hou et al. 2013, Wu et al. 2013].

\section{CONCLUSIONS}

1. The waters of the reservoirs studied are relatively well-oxygenated, though both supersaturation and anoxic conditions are observed seasonally, perhaps indicating the presence of autochthonous organic matter.

2. Bottom sediments are alkaline, and the concentrations of $\mathrm{Mn}$ and $\mathrm{Fe}$ varied between the studied sites across a wide range of values, albeit with the latter still lower than in other reservoirs of this geographical zone.

3. No direct impact of bottom-sediment Fe or Mn content, $\mathrm{Mn} / \mathrm{Fe}$ ratio or $\mathrm{pH}$ on oxygen conditions in the reservoir waters could be detected.

4. Multiple regression analysis nevertheless allowed for the identification of a significant influence of the $\mathrm{Mn}$ content and sediment $\mathrm{pH}$ on the oxygen concentration in the waters studied. In essence, an increase in the Mn content and a reduction in $\mathrm{pH}$ both result in more favorable aerobic conditions in waters.

\section{Acknowledgements}

The research was funded by the Polish National Science Center in the framework of the research project No. 2011/03/B/ST10/04998.

\section{REFERENCES}

1. Bartoszek L., Tomaszek J. 2008. Relationships between phosphorus distribution and major components in the bottom sediments of the Solina-Myczkowce reservoirs. Archives of Environmental Protection, 34, 151-161.

2. Bartoszek L., Tomaszek J.A. 2011. Analysis of the spatial distribution of phosphorus fractions in the bottom sediments of the Solina-Myczkowce dam reservoir complex. Environment Protection Engineering, 37(3), 5-15.

3. Bryant L.D., Hsu-Kim H., Gantzer P.A., Little J.C. 2011. Solving the problem at the source: controlling $\mathrm{Mn}$ release at the sediment-water interface via hypolimnetic oxygenation. Water Research, 45(19), 6381-6392.

4. Czaplicka A., Ślusarczyk Z., Szarek-Gwiazda E., Bazan S. 2017. Spatial distribution of iron and manganese in bottom sediments of the Goczałkowice Reservoir. Ochrona Środowiska, 3, 47-54 (in Polish).

5. Dunalska J.A., Grochowska J., Wiśniewski G., Napiórkowska-Krzebietke A. 2015. Can we restore badly degraded urban lakes?. Ecological Engineering, 82, 432-441.

6. Gantzer P.A., Bryant L.D., Little J.C. 2009. Controlling soluble iron and manganese in a watersupply reservoir using hypolimnetic oxygenation. Water Research, 43(5), 1285-1294.

7. Grabas M., Tomaszek J.A., Czerwieniec E., Zamorska J., Kukuła E., Masłoń A., Gruca-Rokosz R. 2011. Noxiousness of odours and properties of wastewater sludge processing with biopreparation. Environment Protection Engineering, 37(3), $17-25$.

8. Grochowska J., Tandyrak R. 2009. The influence of the use of land on the content of calcium, magnesium, iron and manganese in water, exemplified in three lakes in the Olsztyn vicinity. Limnological Review, 9(1), 9-16.

9. Gruca-Rokosz R., Tomaszek J.A. 2015. Methane and Carbon Dioxide in the Sediment of a Eutrophic Reservoir: Production Pathways and Diffusion Fluxes at the Sediment-Water Interface. Water, Air, and Soil Pollution, 226(2), 2268-2268.

10. Gruca-Rokosz R., Czerwieniec E., Tomaszek J.A. 2011. Methane emission from the Nielisz Reservoir. Environment Protection Engineering, 37(3), 101-109.

11. Hou D., He J., Lü C., Sun Y., Zhang F., Otgonbayar K. 2013. Effects of Environmental Factors on $\mathrm{Nu}-$ trients Release at Sediment-Water Interface and Assessment of Trophic Status for a Typical Shallow Lake, Northwest China. The Scientific World Journal, 716342. doi:10.1155/2013/716342. 
12. Kaleta J., Puszkarewicz A., Papciak D. 2007. Removal of iron, manganese and nitrogen compounds from underground waters with diverse physical and chemical characteristics. Environment Protection Engineering, 33(3), 5-13.

13. Karwacka A., Niedzielski P., Staniszewski R. 2015. Status assessment of the bottom sediments of selected lakes of Poznań district. Rocznik Ochrona Środowiska, 17(2), 1684-1698 (in Polish).

14. Kowalczewska-Madura K., Gołdyn R., Dondajewska R. 2010. Phosphorus release from the bottom sediments of Lake Rusałka (Poznań, Poland). Oceanological and Hydrobiological Studies, 39(4), 135-144.

15. Molenda T. 2013. Iron (Fe) and manganese (Mn) as mining water pollution indicators (on the example of objects from the Upper Silesian Coal Basin). Journal of Civil Engineering, Environment and Architecture, 60(3), 69-78 (in Polish).

16. Naeher S., Gilli A., North R.P., Hamann Y., Schubert C.J. 2013. Tracing bottom water oxygenation with sedimentary $\mathrm{Mn} / \mathrm{Fe}$ ratios in Lake Zurich, Switzerland. Chemical Geology, 352, 125-133.
17. Naeher S., Smittenberg R.H., Gilli A., Kirilova E.P., Lotter A.F., Schubert C.J. 2012. Impact of recent lake eutrophication on microbial community changes as revealed by high resolution lipid biomarkers in Rotsee (Switzerland). Organic Geochemistry, 49, 86-95.

18. Stańczykowska-Piotrowska A. 1990. Ecology of our waters. Wydawnictwa Szkolne i Pedagogiczne (in Polish).

19. Wójcik M. 2016. Seasonal changes in physicochemical and microbiological parameters of water in the gravel pit lake used for recreation. Journal of Civil Engineering, Environment and Architecture, 63(2/I), 387-399 (in Polish).

20. Wu Y., Wen Y., Zhou J., Wu Y. 2014. Phosphorus release from lake sediments: effects of $\mathrm{pH}$, temperature and dissolved oxygen. KSCE Journal of Civil Engineering, 18(1), 323-329.

21. Zeleňáková M., Čarnogurska M., Šlezingr M., Słyś D., Purcz P. 2013. A model based on dimensional analysis for prediction of nitrogen and phosphorus concentrations at the river station Ižkovce, Slovakia. Hydrology and Earth System Sciences, 17, 201-209. 